\title{
A Research on Energy-saving Renovation Project of an Existing Campus Building of Shenyang University
}

\author{
Ruiying Jia ${ }^{1, a^{*}}$, Yemin Zhang ${ }^{1}$ Xin $\mathrm{Li}^{1, \mathrm{~b}}$ \\ ${ }^{1}$ Shenyang University ,China \\ ajiaruiying6@163.com \\ blixin200101@163.com
}

\begin{abstract}
Keywords: existing buildings; building envelope; energy saving renovation Abstract. This paper introduces the suitable technologies for energy-saving renovation project of an existing campus building of Shenyang University, with its emphasis on energy saving works of building envelope (external wall, external window and roof), it also analyzes energy consumption reduction ratios and the resulting benefits after the energy-saving renovation.
\end{abstract}

\section{Introduction}

For the purpose of economic development, air pollution reduction, environment protection and thermal environment improvement for the buildings, China has carried out massive research works in the field of energy-saving construction and green building since the"11th Five-year Plan", including implementation of science and technology supportive program project "Researches and Examples on Key Technologies for Constructional Energy Saving", "Researches and Examples on Key Technologies for Comprehensive Renovation of Existing Buildings", and "The 12th Five-year-plan" science and technology supportive program project "Evaluation System for Green Buildings and Research and Development of Standard Technologies" which is currently being implemented, etc. With the promulgation and implementation of the < Green Building Evaluation Standard $>$ GB/T50378-2014 、<Civil Green Building Design Standard $>$ JGJ/T229-2010 and other green building standards, the concept of green building has become the new developmental direction of building energy saving constructions in our country. "Green Building Course of Action plan" has clearly pointed out our national developmental direction of construction, which included practical and effective supervision of building energy saving constructions, and vigorous promotion of energy saving renovation of existing buildings. The city's new office buildings have already been built in accordance with the requirements of the $<$ Energy Saving Design Standard for Public Buildings DGJ08-107-2012>, as for the existing huge stock of office buildings as big as billions square meter construction area, due to the factors of low performance parameters of the building structure, low energy efficiency of the system, and poor operation management, etc., the total energy consumption is inevitably excessive, and will continue to grow with the advance of the buildings' life cycles. Therefore, energy-saving renovation of existing office buildings is of very important practical significance for building cities of "resource-saving and environment-friendly type", and in the meantime, our government is gradually improving its requirements for green buildings, and subsequently, how to realize green renovation of existing office buildings has become a new research focus.

Energy saving in construction is comprised of the following two principle aspects, one is energy saving of the building itself, which is to improve the thermal insulation performance and reduce the heat loss of the retaining structure, the other is system energy saving, which is to improve the efficiency of building equipment system and reduce the energy consumption of equipment.

Focused on the \#2 classroom building, Shenyang University, this paper researches practical and effective renovation measures to save energy of building envelope structures and analyzes the energy saving benefits resulting from the renovation. 


\section{Thermal parameters of the \#2 classroom building and its retaining structure}

\#2 classroom building, Shenyang University, was built in 1996, and faces to northwest $45^{\circ}$ and covers an area of $3615.4 \mathrm{~m}^{2}$ with $20004.1 \mathrm{~m}^{2}$ construction area, and falls into the category $B$. The Figure coefficient $S$ is 0.11 and the window wall area ratio is 0.68 .It uses radiator heating system in heating season with natural ventilation and no air conditioning system. The retaining structure and the thermal parameters are shown in Table 1, Table 2 and Table 3.

Table1 Roof structural measures and thermal parameters

\begin{tabular}{|c|c|c|c|c|}
\hline number & $\begin{array}{l}\text { Roof structure from } \\
\text { inside to outside }\end{array}$ & $\begin{array}{l}\text { Thermal } \\
\text { conductivity } \\
\lambda\left[\mathrm{w} / \mathrm{m}^{2} . \mathrm{k}\right\}\end{array}$ & $\begin{array}{c}\text { Material } \\
\text { thickness } \\
\delta[\mathrm{m}] \\
\end{array}$ & $\begin{array}{c}\text { Thermal resistance } \\
R=\delta / \lambda\left[\mathrm{m}^{2} . \mathrm{k} / \mathrm{w}\right]\end{array}$ \\
\hline 1 & $\begin{array}{l}\text { 1:3 Cement mortar } \\
\text { plastering }\end{array}$ & 0.93 & 0.02 & 0.021 \\
\hline 2 & $\begin{array}{l}\text { Reinforced concrete } \\
\text { roof pane }\end{array}$ & 1.74 & 0.12 & 0.069 \\
\hline 3 & 1:3 Cement mortar & 0.93 & 0.02 & 0.021 \\
\hline 4 & $\begin{array}{l}\text { Cold essential oil once } \\
\text { again, hot asphalt two } \\
\text { way }\end{array}$ & 0.7 & 0.004 & 0.006 \\
\hline 5 & $\begin{array}{l}\text { 1:10 Cement perlite } \\
\text { insulation layer }\end{array}$ & 0.24 & 0.1 & 0.42 \\
\hline 6 & $\begin{array}{l}\text { 1:8 Cement perlite } \\
\text { sloping }\end{array}$ & 0.39 & 0.06 & 0.154 \\
\hline 7 & $\begin{array}{l}\text { 1:3 Cement cement } \\
\text { mortar }\end{array}$ & 0.93 & 0.02 & 0.021 \\
\hline 8 & $\begin{array}{l}\text { Polyurethane } \\
\text { waterproof coating } \\
\text { three degree }\end{array}$ & 0.25 & 0.007 & 0.028 \\
\hline 9 & 1:3 Cement mortar & 0.93 & 0.02 & 0.021 \\
\hline
\end{tabular}

Table 2 Exterior wall structural measures and thermal parameters

\begin{tabular}{clccc}
\hline number & $\begin{array}{c}\text { Exterior wall structure from } \\
\text { inside to outside }\end{array}$ & $\begin{array}{c}\text { Thermal } \\
\text { conductivity } \\
\lambda[\mathrm{w} / \mathrm{m} 2 . \mathrm{k}]\end{array}$ & $\begin{array}{c}\text { Material } \\
\text { thickness } \\
\delta[\mathrm{m}]\end{array}$ & $\begin{array}{c}\text { Thermal resistance } \\
R=\delta / \lambda\left[\mathrm{m}^{2} . \mathrm{k} / \mathrm{w}\right]\end{array}$ \\
\hline 1 & In cement mortar lastering & 0.93 & 0.02 & 0.021 \\
2 & Cork brick & 0.58 & 0.370 & 0.638 \\
3 & Cement mortar & 0.93 & 0.02 & 0.021 \\
4 & Polymer mortar protection layer & 0.86 & 0.02 & 0.023 \\
5 & facing tile & 1.5 & 0.012 & 0.008 \\
\hline
\end{tabular}

Table 3 Doors, windows, curtain wall structure and heat transfer coefficient

\begin{tabular}{clccc}
\hline Name & \multicolumn{1}{c}{ Type } & $\begin{array}{c}\text { Air layer } \\
\text { thickness }[\mathrm{mm}]\end{array}$ & $\begin{array}{c}\text { Glass } \\
\text { thickness }[\mathrm{mm}]\end{array}$ & $\begin{array}{c}\text { Heat transmission } \\
\text { coefficient[W/m .k] }\end{array}$ \\
\hline $\begin{array}{c}\text { Outer } \\
\text { window }\end{array}$ & $\begin{array}{l}\text { Single window glass } \\
\text { aluminum frame }\end{array}$ & $100-140$ & 5 & 3.0 \\
$\begin{array}{c}\text { Outer } \\
\text { door }\end{array}$ & $\begin{array}{l}\text { Single glass luminum } \\
\text { frame door }\end{array}$ & & 5 & 6.4 \\
Curtain & Insulating glass & 12 & 5 & 3.2 \\
\hline
\end{tabular}


Total thermal resistance of building envelope $R=$ Internal surface thermal resistance $0.11+$ Total heat resistance of roofing structure $R_{0}+$ Outside surface $0.04 \mathrm{~W} /(\mathrm{m} 2 \cdot \mathrm{K})$.[1] Heat transfer coefficient of building envelope $K=1 / R$. Considering the influence of the structural cold bridge and the material with the use of the time, the thermal performance of the thermal performance is attenuated, Average heat transfer coefficient $K m=1.2 \mathrm{~K}$. So the total thermal resistance $R_{0}$ of roof and exterior wall are respectively 0.761 and $0.711 \mathrm{~m}^{2} \cdot \mathrm{K} / \mathrm{W}$. Average heat transfer coefficient of roof and exterior wall $\mathrm{Km}$ are respectively1.1 and $1.2 \mathrm{~W} / \mathrm{m}^{2} \cdot \mathrm{K}$.

\section{Energy saving reconstruction scheme of \#2 classroom building envelope}

The provisional indexes of public building energy efficiency design requirements include:Building shape coefficient; the window wall area ratio and design selection window heat transfer coefficient, typical structure level and average heat transfer coefficient of roof, typical structural level and verageheat transfer coefficient of wall. The requirements of the thermal design of the building envelope with the shape coefficient S0.3 in $<$ Public building energy efficiency design standard GJ081072012> stated in the Table 4.

Table 4 Heat transfer coefficient limits of $S \leqslant 0.3$ for building envelope

\begin{tabular}{ccccc}
\hline $\begin{array}{c}\text { Exterior-protected } \\
\text { construction }\end{array}$ & Roofing & $\begin{array}{c}\text { Outer window (including } \\
\text { transparent curtain wall) }\end{array}$ & $\begin{array}{c}\text { Outer } \\
\text { door }\end{array}$ & $\begin{array}{c}\text { Outer } \\
\text { wall }\end{array}$ \\
\hline $\begin{array}{l}\text { Limit of heat transfer } \\
\text { coefficient } K\left[\mathrm{w} / \mathrm{m}^{2} . \mathrm{k}\right]\end{array}$ & $\leqslant 0.45$ & $\leqslant 1.8$ & $\leqslant 2.6$ & $\leqslant 0.5$ \\
\hline
\end{tabular}

Comparison displays that the heat transfer coefficient of building envelope of \#2 classroom building does not comply with the current energy saving building standard. The room for energy saving renovation is more than enough.

\section{Exterior wall energy saving renovation}

The wall is the main body of the building's exterior envelope. The thermal insulation properties of the used materials directly affect the energy consumption of buildings. The existing building masonry structure cannot be changed, so we can only use wall heat preservation method to reduce heat loss. By insulation position, external wall insulation is categorized into internal heat insulation, exterior insulation and median insulation. Median insulation cannot be applied to existing buildings' outer walls. By thermal insulation material, there are 4 kinds of heat preservation methods: foamed polystyrene board (EPS plate)thin plastering system, extruded polystyrene board(XPS plate)thin plastering system, polyphenyl granule system, hard foam polyurethane spraying system. Considering renovation costs, construction process, indoor environmental impact, energy saving effect and other factors, this building exterior wall heat preservation renovation is suitable for use of $80 \mathrm{~mm}$ thick, $18 \mathrm{Kg} / \mathrm{m}^{3}$ volume-weight, $0.042 \mathrm{w} /\left(\mathrm{m}^{2} . \mathrm{k}\right)$ thermal conductivity foamed polystyrene board (EPS board) thin plastering exterior insulation system.

\section{Outer doors and windows energy saving renovation}

The weakest part of building envelope thermal performance is the outer window. Under the onditions of meeting the requirements of sunshine, lighting, ventilation and sight-viewing, reduction of the size of the outer doors and windows of the building, improves the air tightness and heat preservation performance of the doors and windows and reduces the outer window heat transfer. In consideration of the requirements for the classroom building's area of the doors and windows and the evaluated difficulty of construction, \#2 classroom building is not suitable for reducing the area of the outer doors and windows, outer doors and windows energy saving renovation should change window frames and use low-e glass or insulated glass. Aluminum frame, white glass, double windows were originally used in \#2 classroom building. Two schemes are available for the renovation: one is to replace the outer window with low-e glass with plastic frame, without changing the inner layer windows, the other one is to use single window with thickness of $6+12+6$ hollow low-e glass plastic frame to replace the original double windows. And the original single aluminum frame, single-layer glass doors are to be replaced by plastic frame, low-e glass doors. By renovation like this, the heat transfer coefficient of external windows is reduced to $1.77 \mathrm{w} /\left(\mathrm{m}^{2} . \mathrm{k}\right)$, which is conformed with the 
current energy-saving building standards. Insulated glass curtain wall was originally used, is not to be changed.

\section{Roof energy saving renovation}

Common measures for roof reconstruction is to change flat roof to slope roof, as in "flat to slope", and to add thermal insulation layer to the roofing."Flat to slope" measure not only increases thermal performance of the top floor, but also is conducive to waterproof. But the construction difficulty and cost are much higher than measure of adding insulation layer.

To ensure the roof load requirements and intensity of material, $80 \mathrm{~mm}$ thick, $30 \mathrm{~kg} / \mathrm{m}^{3}$ volume-weight, $0.03 \mathrm{w} /\left(\mathrm{m}^{2} . \mathrm{k}\right)$ thermal conductivity XPS insulation board is suitable for \#2 classroom building roof energy saving renovation.

\section{Analysis of energy saving benefit of building envelope of \#2 classroom building}

\section{Annual energy saving from the renovation}

For \#2 classroom building envelope energy saving, see Table 5.

Table 5 Energy saving energy saving from renovated building envelope

\begin{tabular}{|c|c|c|c|c|c|c|c|}
\hline \multirow[t]{2}{*}{ name } & \multicolumn{2}{|c|}{$\begin{array}{c}\text { Heat transfer } \\
\text { coefficient }[\mathrm{w} / \mathrm{m} . \mathrm{k}]\end{array}$} & \multirow{2}{*}{$\begin{array}{c}\text { Reform } \\
\text { area } F \\
{\left[\mathrm{~m}^{2}\right]}\end{array}$} & \multirow{2}{*}{$\begin{array}{c}\text { Average temperature } \\
\text { difference of indoor } \\
\text { and outdoor heating } \\
t_{n}-t_{e}\left[{ }^{\circ} \mathrm{C}\right]\end{array}$} & \multirow{2}{*}{$\begin{array}{l}\text { Days of } \\
\text { heating } \\
N[\mathrm{~d}]\end{array}$} & \multirow{2}{*}{$\begin{array}{c}\text { Energy } \\
\text { savin } \\
Q[\mathrm{kwh} / \mathrm{a}]\end{array}$} & \multirow{2}{*}{$\begin{array}{c}\text { Energy } \\
\text { saving } \\
\text { efficiency } \\
\eta\end{array}$} \\
\hline & $\begin{array}{c}\text { Before } \\
K_{l}\end{array}$ & $\begin{array}{l}\text { After } \\
K_{2}\end{array}$ & & & & & \\
\hline $\begin{array}{l}\text { Outer } \\
\text { wall }\end{array}$ & 1.2 & 0.37 & 3056 & & & 218390 & $69 \%$ \\
\hline $\begin{array}{l}\text { Outer } \\
\text { window }\end{array}$ & 3.0 & 1.77 & 2656 & $18-(-5.6)$ & 152 & 281280 & $41 \%$ \\
\hline Roofing & 1.1 & 0.28 & 3300 & & & 232990 & $74 \%$ \\
\hline $\begin{array}{l}\text { Outer } \\
\text { door }\end{array}$ & 6.4 & 1.77 & 106 & & & 42260 & $72 \%$ \\
\hline
\end{tabular}

\section{Economic and environmental benefits from energy saving renovation}

\#2 teaching building, Shenyang University, uses the self- built coal boiler for winter heating. Operational formula of annual coal saving is:

In this formula:

$$
G=3.6 \triangle Q /\left(\eta_{1} \times \eta_{2} \times Q_{y d w}\right)
$$

$G$-annual coal saving,t/year;

$\eta_{1}$ - average thermal efficiency of boiler, 0.70 ;

$\eta_{2}$ - heating efficiency, 0.90 ;

$Q_{y d w}$ - low calorific value of standard coal, $18840 \mathrm{~kJ} / \mathrm{kg}$ [3]

Determined by calculation, $774920 \mathrm{kwh} / \mathrm{a}$ energy saving from the renovation is equivalent to $235 \mathrm{t}$ bituminous coal of annual saving. Meanwhile, emissions of hazardous substances: $\mathrm{CO}_{2} 698 \mathrm{t}, \mathrm{CO}$ $10.6 \mathrm{t}, \mathrm{SO}_{2} 7.9 \mathrm{t}$,NO 27.5t,suspended matter $0.7 \mathrm{t}$; ash $102.8 \mathrm{t}$ can be reduced within a heating season.

\section{Conclusion}

The proposed energy saving renovation of \#2 classroom building, Shenyang University, complies with current public building energy efficiency standards and brings about considerable economic and environmental benefits. 


\section{Acknowledgements}

This work was financially supported by the Science and Technology Project of Shenyang (F15-114-9-00).

\section{References}

[1]Ximin Zhang.Zepei Ren.Heat transfer theory[M].Beijing:China Building Industry Press,2013,ISBN978-7-112-09183-6

[2]Ping He.Heating project[M].Beijing:China Building Industry Press,2013, ISBN978-7-112-10849-7

[3]Weilong Wu, Junyan Jiang.Boiler and boiler room equipment[M].Beijing: China Building Industry Press, 2014, ISBN 978-7-112-16865-1 